\title{
“PRIEST-DOCTORS” AS A RURAL HEALTH SERVICE IN THE AGE OF ENLIGHTENMENT
}

by

\section{ROBERT HELLER*}

THE EXTENSION of medical care and health education in remote and sparsely populated rural areas has now become one of the main objectives in the plans for the development of health services throughout the world. Rural health services are receiving, deservedly, a high place in the order of priorities of development planning.1,2

In some countries rural health schemes have already been successfully established on a large scale as, for example, in Russia ${ }^{8}$ and China. ${ }^{4}$ It has been generally realised that any extension of medical care on a large scale cannot, for various reasons, be achieved by creating a large additional supply of fully trained doctors in rural areas. It has been found necessary to build up a cadre of auxiliary health personnel to deal with the primary health care of the population. The great interest in schemes of this nature is by no means confined to those who are entrusted with the improvement of the health of developing countries. In the U.S.A. a number of schemes employing auxiliaries are now on trial, ${ }^{5}$ and in Canada ${ }^{6}$ and Great Britain ${ }^{7}$ the possibility of creating health care teams relying primarily on para-medical personnel is being explored.

The attention given to rural health problems, especially in developing countries, and the proposed means to deal with them may seem novel to us at the present time. However, the importance of adequate medical care in agricultural areas had been recognized long ago and measures to relieve the plight of the rural population have been proposed from time to time in different European countries. The suggested methods to deal with the problems of under-doctored countries then differ remarkably little from those which are expected to remedy the lack of suitable health personnel in similiar locations in our time.

In the eighteenth century the main deficiencies which were then thought to merit

"Robert Heller, M.D., Wellcome Institute for the History of Medicine, 183 Euston Road, London NW1 2BP.

1 Gordon Wolstenholme (editor), Teamwork for world health, London, Churchill, 1971.

2 Rex N. E. Fendall, Auxiliaries in health care, Baltimore, Md., Johns Hopkins Press, 1972.

- World Health Organization, Report on the inter-regional travelling seminar on the training and utilization of medical assistants (Feldshers) in the U.S.S.R. 29.9.-29.10.1967, Geneva, W.H.O., 1967.

- Joseph R. Quinn (editor), Medicine and public health in the People's Republic of China, Bethseda, Md., Department of Health, Education and Welfare, 1973.

- Richard A. Smith, 'Medex', Lancet, 1973, ii: 85-87.

- Walter D. Spitzer et al., 'The Burlington randomized trial of the nurse practitioner', New Engl. J. Med., 1974, 290: 251-256.

' British Medical Association, Primary health care teams, London, B.M.A., 1974. 


\section{Robert Heller}

the attention of the state existed chiefly in the sometimes vast, underpopulated agricultural areas of Europe. The conditions prevailing there presented a mirror-image of the situation in the developing countries at present. The main obstacles to progress were basically the same as they are today in the countries of the third world. Difficult communications and the prevailing social and political conditions had led to the neglect of the needs of the rural population. The results were poverty, ignorance and ill health.

The twin causes of lack of medical care in country districts were then, as now, scarcity as well as maldistribution of medical personnel. A third factor was the poverty of the population. However, even if an inhabitant of a rural area could afford the fees of a fully qualified doctor, it was doubtful if medical help could reach him within reasonable time, in view of the difficult travelling conditions. In some cases the physician would even refuse to undertake the strenuous and often hazardous journey. Under these circumstances it is not surprising that in case of illness or accident recourse was taken to remedies of folk medicine, often prescribed and administered by some "wise" man or woman in the village. Very often, however, the lord or lady of the manor or the parish priest were consulted as persons of superior knowledge. , $9^{2}$

Thus the custom developed to rely in medical matters on the advice and the assistance of educated lay persons, who were very often the only ones in the locality who could read and write. This created a need for books on medicine of a somewhat simplified character, providing advice on the treatment of most medical conditions for which help would be asked for, as well as the description of simple medicines and perhaps also instructions for the preparation of such remedies. In the eighteenth century many books on "popular medicine" were published and achieved a large readership. Already in the first half of the seventeenth century Guibert's Le médecin charitable and L'apothecaire charitable were written for the use of the clergy, of religious communities and of noble families. ${ }^{10}$

The book on "popular medicine" with the widest circulation, which was probably more often consulted than any other similar book was Tissot's Avis au peuple sur sa santé. In the introduction ${ }^{11}$ the author states that his work was not intended for the use of physicians, but he was likewise not under the illusion that his book would be found in the house of every peasant, as the title might imply. Many would be unable to read it and even more would not be able to understand it. Then he writes: “. . . I have principally calculated it for the perusal of intelligent and charitable persons, who live in the country and who seem to have, as it were, a call from provi-

- Conditions in Scotland are described by John D. Comrie, History of Scottish medicine, London, Baillière, 1932, vol. I, p. 224.

- Johann Christian Reil comments on the peasants' attitude to medicine in eighteenth-century Germany: "[. . . The peasant] prefers to consult the Lady of the Manor who will give the poor rubarb rather than bread, as she can thus show not only her graciousness, but also her medical knowledge." See Pepinieren zum Unterricht ärztlicher Routiniers als Bedïrfnisse des Staates nach seiner Lage wie sie ist, Halle, Curt, 1804, p. 13.

${ }_{10}$ Philibert Guibert, Le médecin charitable and L'apoticaire charitable, Paris, 1632. Both works were published in one volume. An English translation was published in London in 1639 under the title The charitable physitian with the charitable apothecary.

11 Samuel Auguste David Tissot, Avis au peuple sur sa santé, Lausanne, Zimmerli, 1761, pp. 1-27. 


\section{"Priest-doctors" as a rural health service in the age of Enlightenment}

dence, to assist their less intelligent poor neighbours with their advice. It is obvious that the first gentlemen I have my eye upon, are the clergy. . .."12

The book that followed Tissot's Avis au peuple, which was based on its predecessor and which was to become its rival, especially in the British Isles and in North America, was Buchan's Domestic medicine. In its advertisement ${ }^{12}$ Buchan writes: "We make no doubt but the ladies, gentlemen and clergy who reside in the country will readily concur with us, in the endavouring to root out such pernicious prejudices. Their example will have great weight with their dependants \& inferiours and their advice will be often listened to with more attention than that of a physician. ..."

John Wesley's Primitive physick ${ }^{18}$ was in the first instance meant to assist patients to treat themselves, although Wesley himself had opened dispensaries for the sick poor in London, Bristol and Newcastle. He also gave medical advice to the poor on his travels. ${ }^{14}$

Tissot's compatriot, the Swiss physician Johann Friedrich von Herrenschwand ${ }^{15,16}$ writes in the preface to his book Traité des principales et plus fréquentes maladies ${ }^{17}$ that he would describe simple remedies for the benefit of travellers and of the poor, remedies which could be found in any pharmacy or even in simple medicine chests, as kept by country families, priests or other people, who, for humanitarian reasons practised medicine. ${ }^{18}$ In 1795 Herrenschwand gave 150 copies of his book to the medical library in Berne for distribution to priests and country doctors. One hundred copies of the German edition were distributed from Berne, and fifty copies of the French one from Lausanne. ${ }^{19,20}$

At the end of the seventeenth century the first attempts were made in France to extend medical care in times of epidemics to remote rural areas, served only by barber-surgeons, apothecaries, spicers and other unqualified practitioners. For this purpose the rural clergy seemed to be the most suitable instrument of the state. From 1693 onward the director of the French treasury (directeur des economats) d'Agusseau established the practice to send medicines for free distribution to bishops, administrators of hospitals, lords of the manor (seigneurs de paroisses), parish priests

12 William Buchan, Domestic medicine, Edinburgh, 1769, pp. vii-xiv

13 John Wesley, Primitive physick, London, T. Trye, 1747. (Edition used: London 1845.)

16 Wesley A. Hill, John Wesley among the physicians, London, Epworth Press, 1958, pp. 46-48.

1s Johann Friedrich von Herrenschwand (1715-1798), German-Swiss physician, born in Murten, Switzerland in 1715. He obtained the degree of doctor of medicine at the University of Leyden in 1737 where, for a short time, he had been a pupil of Boerhaave, after working at the military hospital at Tournay as physician to a Swiss regiment. He was appointed physician-in-ordinary to the Prince of Saxony-Gotha. From 1750 to 1755 he was physician to the Swiss Guard in Paris. He then set up in practice in his native town of Murten until King Stanislas of Poland appointed him as his physicianin-ordinary in 1766. Herrenschwand returned to Switzerland after only three years. On invitation of the town council he finally set up in practice in Berne in 1779.

16 Hans Jenzer, Dr. Med. Johann Friedrich von Herrenschwand, Berne, Francke, 1967, contains a full account of Herrenschwand's. work and full biographical data as far as they are known.

17 Johann Friedrich von Herrenschwand, Traité des principales et des plus fréquentes maladies externes et internes, Berne, Seizer, 1788.

18 Ibid., pp. 2-3.

10 Jenzer, op. cit., note 16 above, pp. 29 and 243.

so Herrenschwand's book was published in a French and German edition. In 1789 an Italian one was published in Milan. It was dedicated by the translater to Johann Peter Frank, Tissot's successor as professor of medicine in Pavia. 


\section{Robert Heller}

and to the nursing order of the Grey Nuns (soeurs grises). ${ }^{21,22}$

From 1769 onward chests were prepared, containing medicines for distribution in country districts. These medicine chests were kept as light as possible, as transport was extremely costly. An order of the council of 1 March 1769 established the number of chests containing the remèdes $d u$ Roi at 742 small chests and thirty-two large ones. ${ }^{23}$ The active co-operation of the rural clergy was thought to be especially important during epidemics, when the distribution of medicines and also of financial help was organized by the state. Many clergymen were reported to have died in consequence of having given assistance to their rural parishioners. At the turn of the century the rural clergy were also requested to advance the cause of health education by persuading their congregations to accept vaccination against smallpox. ${ }^{24,25}$

In France the assistance of the rural clergy was enlisted in the first place as an emergency measure in times of epidemics only. Although the members of the French rural clergy, as everywhere else in Europe, gave medical aid to their parishioners individually, when needed, there existed no scheme during the ancien régime to integrate them into a system for the medical care of the poor which was administered or at least initiated by the state.

An important role was played by the Christian clergy, irrespective of denomination, in the extension of medical aid to rural populations overseas through missionaries. This activity, commencing in the sixteenth century, greatly expanded throughout the centuries, reaching eventually almost every corner of the inhabited world. However valuable the missionaries' work in regard of health care in developing countries has been in the past and indeed still is at present, its influence on the health of the different communities in which it was performed remained on the whole on a restricted local scale. The impact of missionary work on rural community health throughout the world deserves an impartial detailed study, which is long overdue. It is, however, not immediately relevant to the concepts to be discussed here.

The statesman and administrator in the age of enlightenment was faced with everincreasing demands for the extension of medical care and of measures to improve community health. It had become recognized as a principle of wise statesmanship to look after the health of the population, as well as to promote its increase in number. The wealth of a nation was considered to depend on a constantly increasing number of healthy citizens. ${ }^{26,27,28}$ To the administrator the concept of "priest-doctors" must have seemed particularly attractive. There was a large body of educated men who were placed in parishes all over the country, very often in villages where no other

"Camille Bloch, L'assistance et l'état en France da la vielle de la revolution, Paris, Ricard, 1906, pp. 240-242.

22 Bibliotheque Nationale, Fonds, Fr.6801, Fo 327. Quoted by Bloch, op. cit., note 21 above.

23 Ibid., pp. 242-245.

${ }^{24}$ Paul Delauney, La médecine et l'église, Paris, Édition Hippocrate, 1948, p. 121.

${ }_{25}$ Paul Delauney, La vie médicinale aux XVIe, XVIIe et XVIIIe siècles, Paris, Edition Hippocrate, 1936, p. 270.

26 Johann Peter Frank, System einer vollständigen medicinischen Polizey, 2nd edition, vol. 1, Mannheim, Schwann, 1784, pp. III-XI.

"27 George Rosen, 'Cameralism and the concept of medical police', Bull. Hist. Med., 1953, 28 : $31-42$.

${ }^{28}$ Eli F. Heckscher, Mercantilism, London, Allen \& Unwin, 1934, vol. 2, pp. 158-161. 


\section{"Priest-doctors" as a rural health service in the age of Enlightenment}

professional man would wish to live. These men would carry out the orders of the central authority on instructions which would either be issued to them directly, or conveyed to them by way of the hierarchy of the Church. If one could induce these persons to acquire a modicum of medical knowledge during the period of their theological studies, the state would then have on hand a ready-made medical service for rural areas at little additional cost to the treasury. Furthermore, this service would at last bring medical care, as well as health education to the areas where they were most needed, the outlying sparsely populated country districts.

In Scandinavia the inhabitants of rural areas were in a particularly precarious position in case of illness owing to the lack of communications and the scattered population. Fully qualified doctors were virtually unobtainable in the country. Salaried Provincial Medici were appointed by the state, but were by no means able to provide a satisfactory medical service. It is, therefore, not surprising that the local priest would be consulted in case of illness or accident. Linnaeus, on a journey through the Swedish province of Skånen, made the acquaintance of Probst Martin Lindevall at Everlöv on 3 July 1749. This priest had made a considerable reputation for himself as a doctor amongst his parishioners. Linnaeus mentions this in the account of his journey ${ }^{20,80}$ and finally says:

The poor peasant shuns the pharmacy, where life is often sold at a high price, he dreads physicians and surgeons which he does not know how to choose. He puts his greatest trust in his own priest and likes to ask his advice in an emergency. It would be of very great benefit to the state if most rural clergymen would understand how to cure the most common diseases, which destroy so many thousands of country folk every year. Most of them are easily cured like dysentery, scurvy, erysipelas, leg ulcers, acute fevers and intermittent fevers. All this knowledge can be learned by the students while they are still at university within eight days at the most. How fortunate would the peasant be, if their priests could heal these ills with the medical herbs that can be got without cost, as they grow in front of the door of everybody's house. What advantage would that be for the state, what pleasure and honour would this not bring to the priests themselves!

Despite Linnaeus's somewhat over-optimistic statement that all that a country priest needed to know about medicine could be learned within one week, to his students there seemed plenty to be learned from Linnaeus's lectures. Stoever in his biography of Linnaeus reports that these were not only attended by medical students but also by students of theology. ${ }^{31}$

During the second half of the eighteenth century the subject of "priest-doctors" was not infrequently discussed, especially in protestant countries. Sweden, however, was the only country where eventually, but not before the first decade of the nineteenth century had elapsed, practical steps were taken to put a "priest-doctor" scheme into action.

The discussion of this topic in the different European countries was reported and commented on in detail by Johann Peter Frank, the author of the monumental System einer vollständigen medicinischen Polizey, who devoted one hundred pages of

20 Carl von Linné, Skanska resa, Stockholm, Lars Salvii, 1751, pp. 274-275.

${ }^{20}$ Heinz Goerke, 'Medizinische Ausbildung von theologischen Studenten an der Universität Lund von 1813 bis 1840' in Hans-Heinz Eulner et al. (editors), Medizingeschichte in unserer Zeit, Stuttgart, Enke, 1971, pp. 352-358 (see p. 352).

${ }^{81}$ Dietrich Heinrich Stoever, Das Leben des Ritters Carl von Linné, Hamburg, 1792, vol. 7, p.298. 


\section{Robert Heller}

his encyclopaedic work on community health to consider this possibility to create, at little cost to the state, a nation-wide rural health service. The volume on medical education, in which he deals with the concept of "priest-doctors" was, however, not published until 1817 , only a few years before his death, ${ }^{32}$ but there can be little doubt that Frank had given this problem a great deal of thought long before that date. In his capacity of professor of practical medicine at the University of Vienna he delivered in October 1803 his Akademische Rede ïber Priester-Aerzte. ${ }^{38}$ This academic address was delivered not long before Frank was to leave Vienna to take up his new appointment in Russia in 1804. There Frank could expect to find a very low standard of health care for the rural population, lower than anywhere in the Habsburg Empire and indeed lower than anywhere else in Europe.

Since the twelfth century the Roman Catholic Church did not allow her ordained clerics to practise medicine or surgery, ${ }^{34}$ although some exceptions were made for missionaries in foreign lands. ${ }^{35}$ For a man like Frank, who professed himself to be an obedient son of the Roman Catholic Church, ${ }^{36}$ it was already a delicate task to advocate the large-scale practice of medicine and surgery by ordained priests of his religion. To do so in Austria in an academic address in the presence of the whole academic body, as well as of many visitors, including many high-ranking government officials and dignitaries of the church, in a country where the church kept a tight rein on every activity, this required a great deal of tact. This we can perceive in the closing passages of Frank's address.

In the introduction to his oration Frank says: "I shall show firstly, that since times immemorial all great nations in antiquity practised medical science in connection with theology and jurisprudence. Secondly, that these sciences walked hand in hand during the first thousand years of Christianity. Thirdly, that neither theology nor jurisprudence can dispense with knowledge of medical matters without detriment

32 Frank, op. cit., note 26 above, volume 6, part 2, Vienna, Schaumburg, 1817, pp. 378-478.

23 Johann Peter Frank, 'Akademische Rede über Priester Arzte, gehalten zu Wien, den 17. Oktober 1803', in Taschenbuch der Wiener Universität für das Jahr 1804, Vienna, 1804.

* The following were some of the church councils which issued edicts forbidding the practice of medicine and surgery by ordained priests: Council of Clermont (1130), Council of Rheims (1133), Lateran Council (1139), Council of Tours (1163), Council of Montpellier (1195). We can assume from the repeated issue of edicts on the same subject that the councils' prohibitions had not been generally observed. See Paul Diepgen, Theologie und der ärztliche Stand, Berlin, Rothschild, 1922, p. 68.

${ }^{26}$ In the "lands of the Heretics and Infidels", or as Carolus a Breno puts it "In the places where the Heretics go about unpunished" (in locis ubi Haeretes impune grassantur), the missionaries were allowed to practise medicine and even surgery. They were deemed to be justified to give medical assistance, provided that they had some knowledge of the subject and that there was no other doctor available. If, therefore, a missionary's patient died, the missionary could not be held responsible, provided he had treated him according to the rules. See Carolus Franciscus a Breno, Manuale missionarium Orientalium, Venice, Typographia Balleoneana, 1726, pp. 64-65 and pp. 123-125. See also Leonardo Correnti, 'Istruzioni di carattere medico per i missionari del XVIII secolo', Medicina nei secoli, 1970, 7: 45-47. This article refers to an abridged edition of Carolus a Breno's book, published in Rome in 1737.

26 Johann Peter Frank, op. cit., note 26 above, p. XII. In the same volume however, he strongly criticizes the Church in the chapter On religious celibacy. See ibid, pp. 146-191. Regarding his own family, Frank showed his liberal attitude towards religion when his daughter Elisabetha was born in Protestant Goettingen in 1784. He declined the Protestant pastor's offer to call a Catholic priest to Goettingen to perform the baptism. Instead he had the child baptized by the selfsame Protestant pastor. See Johann Peter Frank, Seine Selbstbiographie, edited by Erna Lesky, Berne, Huber, 1969. p. 94. 


\section{"Priest-doctors" as a rural health service in the age of Enlightenment}

to themselves". 37

Frank then commences his essay on the history of the priesthood in ancient times and their occupation with healing. He describes how some individuals in different societies withdrew from everyday life to devote themselves entirely to the pursuit of wisdom and to concern themselves with the spiritual and physical well-being of their fellow men. In Egypt the priesthood wielded enormous authority not only as the interpreters of the will of the gods, but also as keepers of the secrets of healing. Some classical authors stated that the ancient Egyptian writers made no definite distinction between the subjects of religion, astronomy and medicine.

The ancient Jews derived their knowledge of medicine from the Egyptians. Their priests were also learned in law and medicine and it was well known that the Levites possessed religious as well as medical knowledge. The Jewish priests had to decide whether a person suffered from leprosy or only from a harmless skin ailment. According to Josephus, the Essenes were particularly dedicated to the study of spiritual as well as physical sciences, which earned them the name of therapeutae or healers.

Strabo wrote that, next to the hermits, the physicians occupied the highest place in the regard of the ancient Indians. Gründler, a missionary in Malabar, reported that only members of the priestly caste of Brahmins were allowed to practise medicine.

Very similar conditions to those in Egypt prevailed in the lands of the ancient Chaldeans and Persians. The religion founded by Zoroaster combined magic with medicine, and astrology became the main preoccupation of the physicians. In ancient Greece priest and physician were combined in the same person, especially in the temples of Aesculapius.

The ancient Romans elevated the concept of health to the divine status of a goddess and the priests were consulted as physicians in their own right. In ancient Germany, where the art of healing had been, as in Scythia and in Gaul, for long in the hands of old women, the Druids had been priests, philosophers, givers of laws, and healers.

As the Jewish priests had been concerned with healing the sick, it was not surprising that the early Christian religious leaders continued with this practice. Christ himself enjoined his disciples to heal the sick and to clean the unclean. There could be little doubt that during the following centuries medicine was exclusively practised by the priesthood. Frank then quotes examples of this with the appropriate references.

Pope Innocent II at the Council of Rheims in 1131 prohibited the study of medicine by monks and clerics on the grounds that the practice of medicine led to excesses due to greed and the neglect of religious rules. This prohibition was repeated by the Lateran Council in 1139 under the same Pope. The council of Tours under Pope Alexander III again forbade the study of medicine by clerics, and later on Popes Honorius III and Boniface VIII repeated this interdiction under the threat of excommunication. Frank asserts that, nevertheless, many clerics practised medicine, especially in France, and gives examples of this. He also mentions that Pope Gregory XIII allowed the Jesuits to practise medicine under the condition that they had the permission of their superiors, that they were sufficiently trained, and that no other doctors were available. This was obviously done with regard to the Jesuits' widespread missionary activities.

"7 Frank, op. cit., note 33 above, pp. 54-60. 


\section{Robert Heller}

Frank now asks the question, whether the segregation of medicine from the Church during the past 600 years had been beneficial or otherwise. He, however, refuses to answer it, arguing that this would be too extensive a subject to be discussed within the narrow frame of an academic address, especially as the Church had already made her decision on it.

He then considers the place of the ancient priest-healers in the history of medicine and finds that, although they had generally been opposed to progress, they had, on the other hand, introduced a number of useful hygienic measures as well as some effective remedies.

The priest-doctors in the early times of Christianity were motivated by charity and by their zeal for the promulgation of their faith. The first hospitals owed their existence to the clergy. Later on, however, when licentiousness and avarice replaced piety and charity, the heads of the Church had to prohibit the practice of medicine by priests.

It was impossible for one man to have a thorough knowledge of all branches of learning, but it was important that judges, magistrates, civil servants and also clergymen should have at least a little knowledge of natural science and medicine, especially those persons who were concerned with the administration of public health and welfare.

He concludes his address as follows: $:^{37}$

In conclusion I should like to make the following points to prove how advantageous it would be if the secular priest, as in the past, would have some knowledge of the most important principles of medicine. I do not wish to say that he should practise the medical science himself, as this would be against the well considered objections of the Church. Nobody could be entrusted to better effect to enlighten the rural population on their most important moral and physical needs than their priests, as only they have their parishioners' confidence. Wise state administrations will use, in whichever country, these priests as their instruments when they wish to persuade the uneducated peasant to accept willingly regulations and suggestions concerned with matters of health.

In times of epidemics, not only among the people, but also among the domestic animals, when the ignorance of the common people is only too often opposing the health regulations, then wise governments make good use of the priest as the leader of the community. Never could previously the so effective inoculation of smallpox and, now in our time, the so much better cowpox vaccination have been introduced so quickly into rural areas without the continuous recommendation and the practical help of the patriotic clergymen. If so much has already been done by the rural clergy without any medical knowledge, how much more could the state expect from them, had they had some instruction in the basic principles of medicine! The piety and zeal of our Christian Sovereign has, in most instances, overcome all obstacles to appoint at considerable cost to the state a priest and a schoolmaster for every community of any size. By this measure the morals, religion and the respect for the law have gained enormously. There can be no doubt that a similar action to improve their physical health would have prolonged the lives and increased the numbers of the rural population considerably. However, how often it has been suggested to supply the people in the country with a sufficient number of physicians and surgeons and how many district doctors' posts it was proposed to create, owing to the lack of funds it was not possible to satisfy the people's needs to any appreciable extent. There are large areas which are insufficiently provided with doctors, so that, especially in winter and when the roads are in bad condition, about two-thirds of the district will be without any medical help in emergencies for at least two or three days at a time. During this time the people have to leave their lives in the untrained hands of the rude barber or if he is not available, in the hands of the nearest quack who can be got. The priest, summoned to the patient on such a melancholy occasion realises with warm commiseration the terrible condition of these unfortunates and tries to ease their misfortune by giving them the comforts of religion. $O$, why had this wonderful opportunity to save human life by combining priest with doctor within one person to be frustrated 


\section{"Priest-doctors" as a rural health service in the age of Enlightenment}

by human passion and abuse! Why had the wise elders of the Church to be forced to decree the complete separation of these two callings?

However, even if the priest is no longer allowed to practise as a doctor, there are hundreds of different ways in which he can be of infinite use to his parishioners, even only in matters of maintaining their good health, provided he has the necessary knowledge. There are many things which cannot be explained to the common people in an official public health regulation, but a wise man with a little knowledge of medicine, although not being a doctor himself, could do this very well. He can teach newly married couples with appropriate dignity the important matters of their married state, which is dedicated to the creation of healthy and useful citizens. He can urge the pregnant women to observe their duty to themselves and their unborn children. He can even supervise the correct rearing of babies. He can also abolish a great number of unhealthy practices by his instructive warnings. He can combat many errors of youth with arguments regarding healthy life, even when his warnings on account of morals remain unheeded. He can warn the people on the results of excesses in food and drink, of the harms of unhealthy food, of unsuitable clothing, and he can prove his arguments with uncontrovertible facts. He can teach young people to recognize poisonous plants and fruits and teach everybody the ways to resuscitate poisoned persons and those who are unconscious but appear to be dead. As well as all this he can also teach the appropriate régime for any illness. The priest can also abolish superstitions that are detrimental to health, life, the honour of true religion and of human reason. He can-but what cannot a man do who is imbued with religion, the love of mankind and with altruism, who is a daily witness of the misery of the poor peasants, which he knows how to alleviate by his wise counsel and with Christian consolation. ...

At the end of his peroration Frank adds the remark that the students of theology would have to acquire the necessary knowledge during their time at university and that he would deal with their training in a further part of his work on Medical police, where he would consider this subject in the section on medical education.

As promised, Frank returns to the subject of "priest-doctors" in the sixth and last volume of his Medicinische Polizey which deals with medical education. This was published in 1817, towards the end of his life, fourteen years after he gave the academic address in Vienna. Section VIII contains his ideas on the training of what he calls lower or lesser practitioners occupying 120 pages, of which Frank devotes one hundred pages to the "priest-doctor". ${ }^{38}$ On the whole he considered partly trained practitioners as detrimental to the nation's health and thought the "home doctor" books on popular medicine to be definitely dangerous. He describes the dichotomy in medical practice then prevailing in France. There were not only fully qualified physicians, but also the officiers de santé who were entitled to practise medicine. The latter would qualify to practise their profession either after six years of apprenticeship with a fully qualified physician or after a five years' apprenticeship in a hospital, or, alternatively after three years of study at a medical school. Frank maintains that only well-educated people should be allowed to practise medicine and, referring to his address on Priest-doctors, ${ }^{39}$ reminds us that priests had since antiquity been concerned with the art of healing.

Frank then reviews the discussion in the German and Swiss literature that had been going on about the training of students of theology for their role in the medical care of their rural parishioners. He quotes Erhardt, ${ }^{40}$ who in 1785 wrote that prospective clergymen were expected to know Greek and Hebrew and to have a great

${ }^{28}$ Frank, op. cit., note 32 above.

" Frank, op. cit., note 33 above.

${ }^{\circ 0}$ F. Erhardt in Archiv der Medicinischen Polizey, vol. 4, Leipzig, 1785, p. 54. quoted verbatim in Frank's Medicinische Polizey, vol. 6, part 2, pp. 379-381. 


\section{Robert Heller}

knowledge of theology. There could be no objection to this, provided that they could make good use of it later on. However, the majority of theological students became rural clergymen, mostly living in places where a different kind of knowledge was needed, and there were neither doctors, nor barber-surgeons, nor apothecaries for miles around. Even nearer to a town it was difficult to persuade a doctor to come out into the country to visit a patient. In most cases the rural population would anyway be too poor to summon a physician from town. Erhardt suggested that at every university a professor of medicine should give a daily lecture on the rudiments of medicine for theological students. The preacher Christian Rudolf Christiani proposed in $1789^{41}$ that prospective preachers should acquire some medical knowledge at medical schools to be able to practise medicine, surgery and health education in the country. An article in the Swiss journal Sammler from 1780 contains the opinion that the priest might rely on books on popular medicine. The anonymous authors $\mathrm{s}^{42}$ write that in past issues of the journal the health of cattle had been discussed, but they felt that the health of the population was far more important. They quote a decree by the Landgrave of Hesse-Darmstadt that stipulates as a condition for a clergyman obtaining a living that he could give proof that he had studied Tissot's book on popular medicine. They also comment favourably on the efforts in some countries to prohibit the practice of medicine by unqualified persons, but believe that this could only be done if sufficient doctors could be appointed in rural areas. In their opinion a clergyman who had studied his Tissot was vastly preferable to a quack. The clergyman, however, should not take up medicine for gain. Medicines should be provided by the community and in addition there should always be some copies of Tissot's book available on loan to interested persons. Midwives should also be appointed, as well as a person who could apply plasters, bandages, clysters, etc. For the future the appointment of salaried doctors and the setting up of hospitals was considered as most desirable. In an unsigned letter from a doctor to a rural priest in the journal Olla Potrida ${ }^{43}$ in 1786 the writer considers it the duty of a clergyman to act as a doctor, but thinks that books on popular medicine, like Tissot's, did more harm than good. The rural clergy should study medicine from medical textbooks like Boerhaave's or Van Swieten's. He is of the opinion that priests should certainly also practise surgery and finally makes the point that Christ was also a healer.

C. W. Hufeland's editorial article on the medical practice of rural clergymen in his Journal der practischen Heilkunde $e^{44}$ is also quoted by Frank. Hufeland gives, on the whole, a favourable opinion on this subject with three provisos: (1) that priests gave their medical services free to their patients; (2) that the priest restricted his practice to his own parish and adjacent localities, so that he should not neglect his clerical duties by extensive travelling; (3) priests should not practise surgery or midwifery so as not to impair their dignity. This would, however, not apply in an emer-

11 Christian Rudolf Christiani, Uber die Bestimmung, Würde und Bildung christlicher Lehrer. Quoted by Frank.

42 "Profs. B. and P.", 'Uber die Frage: ob es rathsam sey, dass sich die Herren Landgeistlichen bey uns der medicinischen Praxis annehmen', Sammler, Chur, 1780, vol. 2, pp. 209-220.

4s 'Schreiben eines Arztes an einen Landgeistlichen', Olla Potrida, Berlin, 1786, 9: 151-155.

« Christian Wilhelm Hufeland, 'Medizinische Praxis der Landgeistlichen', J. prakt. Heilkunde, Berlin, 1809, ii: 1-10. 


\section{"Priest-doctors" as a rural health service in the age of Enlightenment}

gency. ${ }^{45}$ Frank refers briefly to a regulation regarding the medical training of theology students in Sweden, as reported in the Wittenberger Wochenblatt in 1792.46

Frank observes that the above-mentioned proposals only referred to the protestant clergy and as far as medical practice by the catholic clergy was concerned he points out that he himself had made some recommendations in his address on PriesterAerzte in 1803. While doing this he had to keep in mind to proceed with great caution, owing to the prohibition of the practice of medicine and surgery by ordained priests of the Roman Catholic Church. According to him his proposals had been received with approbation by the catholic clergy at the time. Frank explains that he had no hesitation to reprint the main part of the address in the present volume of the Medizinsche Polizey, ${ }^{47}$ as he thought that it formed an important part of a work on medical police and it had previously only been published in journals with a limited circulation.

After having reproduced his exposition of the historical aspects of the "priesthealers," he poses again the question which he had evaded in his original address of 1803. Was the divorce of priesthood from medicine which had continued for the past six hundred years of the Christian era beneficial or otherwise? He comes to the conclusion that it was detrimental to mankind and, moreover, no longer necessary in present times. The abuses that, at one time, had made it necessary for the Church to forbid her ordained priests to practise medicine occurred no longer. On the other hand, if the Church would see fit to allow the rural clergy to study medicine and then to practise it within their parishes the rural population would reap enormous benefit from this. The position of ill people in the country was truly deplorable. The state was in no position to appoint the large number of salaried doctors necessary to look after the health of the people in the vast country districts. The priests would be in an ideal position to alleviate distress and to give good advice on prevention of disease, the rearing of children, and on nutrition. He repeats the catalogue of all the advantages of such a scheme which he gave in his academic address in 1803. In a footnote he mentions reports in German journals of a training scheme in medicine for theological students at the Swedish universities of Uppsala and Lund, ${ }^{48,49}$ as well as Hufeland's proposal..$^{\text {so }}$

In the next paragraph Frank considers the objections that had been made against the creation of "priest-doctors". He declares himself to be very much surprised to have found so much resistance to the concept of "priest-doctors" coming from protestant scholars. As an example he quotes an article on rural clergy in Krünitz's

«s C. W. Hufeland obviously did not think that priest doctors could be regarded to compete seriously with the medical profession. This is in contrast to his opposition to Johann Christian Reil's plan of 1804 to set up training schools for lay auxiliaries. See Reil, op. cit., note 9 above. Hufeland commented unfavourably on Reil's plan, see notes 61 and 62 below.

cs 'Eine Anmerkung über die Krankheitskenntnis der Geistlichen, besonders auf dem Lande', Wittenberger Wochenblatt, 1792, 54: p. 35, quoted by Frank.

${ }^{47}$ Frank, op. cit., note 26 above, vol. 6, part 2, Vienna, Schaumburg, 1817, pp. 386-412.

as 'Uber den Zustand des Medicinalwesens in Schweden', J. prakt. Arzneikunde, 1812, 4: 120-124.

'- Uber den gegenwärtigen Zustand der Medizinanstalt in Schweden', Medsche Nationalztg, 1812, 88: 788-792.

${ }_{\text {so }}$ Hufeland, op. cit., note 44 above. 


\section{Robert Heller}

Oeconomisch-Technologische Encyklopaedie. ${ }^{51}$ The author is of the opinion that the practice of medicine would be detrimental to the authority and prestige of the rural priest. The peasant on the other hand, living in awe of the priest, would probably conceal his ailments from him. Believing in quack medicines and even magic, he would rather consult a quack or a barber-surgeon than a doctor, neither would he be willing to have his wife examined by the priest. The author admits, however, that a certain amount of medical knowledge would be most useful to the rural priest, even if applied only in case of emergency. To this Frank replies that the author himself had made it superfluous to contradict him regarding the important role of the rural priest, but he would prefer the priests to have more than a smattering of medical knowledge.

Objections of a different nature were voiced by Privy-Councillor Gruner ${ }^{52} \mathrm{He}$ maintained that the rural clergy could hardly look after the parishioners' spiritual well-being, quite apart from their bodily health. The rural priests were often of poor quality; they had, as he puts it "neither time, money nor opportunity nor the brains" to acquire even enough knowledge of theology. How could there be room for extra medical learning? The preachers had enough trouble to receive the fees to which they were entitled, who would remunerate them for their medical work? Their money worries let them hardly think about the text of their weekly sermon, they should not be burdened with more than they could bear. Most students of theology were poor and were anxious to finish their studies within two years on account of the cost.

In reply to Gruner's objections Frank reminds him that priesthood and healing had been intimately connected since antiquity and proposals to renew this were by no means absurd. Gruner's opinion of the rural clergy was not justified. Two years, however, were not enough to produce a priest and a doctor in one person. The instruction of theology students in medicine should be arranged by the state free of charge. Regarding lack of time, Frank mentions that many priests had made their reputations as authorities in such subjects as natural history or economics without neglecting their duties. He estimates that, apart from epidemics, the preacher need not devote more than perhaps one hour daily to his medical duties. The priest would, in any case, have to visit his parishioners frequently. Time spent on service to humanity could not be considered as lost.

In the following chapter Frank describes the efforts that had been made to introduce a system of "priest-doctors" in Russia. Frank's personal experience of conditions in Russia dates from the time when he was invited by Tsar Alexander I in 1804 to establish a medical school at Wilna and was appointed court physician at St. Petersburg in $1805 . .^{53} \mathrm{He}$ begins by giving a short historical account of the relations between

61 'Landpfarrer, Landprediger', in Johann Georg Kruenitz, Oeconomisch-Technologische Encyklopaedie, vol. 61, Berlin, 1793, pp. 33-48.

ss Geheimrat Gruner, 'Priesterärzte', Almanach für Ärzte und Nichtärzte, Jena, 1787, pp. 188-192.

${ }^{53}$ At the turn of the eighteenth century Frank's position in Vienna as professor of medicine and director of the Allgemeine Krankenhaus, the 2,000-bedded general hospital, became increasingly precarious. His progressive ideas made him suspect as a possible revolutionary. He accepted Tsar Alexander I's call in 1804, but found neither the physical nor the cultural and political climate of Russia to his liking. He returned to Vienna in 1808 declining all further public appointments. He devoted the rest of his life to his extensive medical practice and to the writing of his monumental Medicinische Polizey and his medical textbook De curandis morbis epitome. 


\section{"Priest-doctors" as a rural health service in the age of Enlightenment}

the Church and medicine, drawing mainly on Richter's Geschichte der Medicin in Russland. ${ }^{54}$ Frank relates that a high-ranking Church dignitary had explained to him that the reason why the Greek Orthodox Church did not allow her clergy to practise medicine was the fear that a priest might kill a patient whilst treating him by an error in treatment. By the same source he was informed that some Russian priests had been known to have practised medicine without hindrance, but not surgery. Frank then refers to a most extraordinary proposal made by Count de Wargemont, who was employed at the Court of St. Petersburg. According to Frank, Count de Wargemont had in 1801 on two occasions submitted his plan to members of the court. This plan is designed to return to the Church not only the practice, but also the teaching of medicine and surgery and is reproduced by Frank verbatim in the original French. ${ }^{55}$ De Wargemont's scheme, if adopted, would have had a profound effect on the teaching and the practice of medicine in Russia and therefore deserves to be described in some detail.

\section{COUNT DE WARGEMONT'S PLAN}

The author starts by describing the difficulties of providing medical care in the rural districts of Russia. He then continues:

I suggest that to the study of theology should be added compulsorily the study of medicine and surgery so that every rural vicar or curate could, or in fact should be obliged to, give his support to the sick. . . . The most common and most justified complaint against the clergy is that they are not fully occupied and one could not possibly provide them with a more dignified and more useful occupation. ... Many people entrust their health and life to a doctor and their soul and salvation to their father confessor. If they would find their spiritual as well as their temporal support combined in one man, he would, without doubt, be regarded with increased respect and affection....

... Also from other important points of view this scheme should have the following advantages:

(1) This is perhaps the only way to enable medicine in general to make good and continuous progress. ... One sees almost every six years the whole system of medicine change completely and being overthrown by a new one which retains nothing of the preceding system, which nevertheless could not possibly have failed to contain some good things. These sudden, complete revolutions which render the discoveries of their predecessors valueless, should never happen in the monasteries, where the art of medicine will be practised and taught. A community does not die like a human being. Tradition, based on the archives should preserve the memory of older treatments and ancient discoveries, while doing no harm to whatever good the new discoveries might have brought to light. The resistance to introduce new discoveries too fast and by this upsetting everything, should certainly only be to the good. On the other hand, one should be able to make the new discoveries known, after being duly tested, and adopt them much quicker than at present. The reason is, quite apart from the discipline of the Church, the cooperation between the ecclesiastics is much better than between the physicians, who much too often reject the discoveries of their colleagues.

(2) Through this scheme the local knowledge of the different districts, of endemics and the special habits of the inhabitants of a certain region. A knowledge which often contributes more to the proper practice of the art of medicine than anything else. A vicar could communicate such knowledge to his curate and he, in turn, to the vicar's successor. . . .

... This twofold education which one could give the young men who intended to enter the priesthood would have another great advantage ... . a man who recognized that he was incapable of practising the priesthood would find himself with another profession and another way of earning his living.

s4 Wilhelm Michael von Richter, Geschichte der Medizin in Russland, Moscow, Wasewolojsky, 1813-1817.

${ }^{65}$ Frank, op. cit., note 26 above, vol. 6, part 2, pp. 438-445. 


\begin{abstract}
Robert Heller
I believe that the greatest obstacle against such a useful project would be the objections from the old ministers of religion, as they resist all innovations. However, a graceful sovereign like our Emperor, our august Master, would, out of his great compassion, employ every means in his power to bring about such a scheme for the great benefit of his subjects. This would at first demand more perseverance and care than money. One would need to reunite the chairs of medicine and surgery and the hospitals with the ecclesiastical schools and seminaries. Inasmuch that such a scheme would be of the greatest advantage of the religion, the clergy and of the poor it would only be right to do this at the expense of the Church. It would also mean increased cost to the nobility, as they would be obliged to give a longer and better education to those whom they meant to place in their livings in the future. There should be little doubt that they would gladly agree to the increased expense for a cause as useful for their subjects as for themselves, as: "By caring for his flock the shepherd thrives". However, if that should not be the case, one would rightly have to put it to them, that whoever owned serfs and other subjects was obliged to give them material as well as spiritual support. It would behove the just Monarch to compel these masters to provide their subjects with physicians and surgeons according to the area to be covered and according to number of subjects they possess, in the same way as the regulations prescribe this now for ships at sea....
\end{abstract}

The author finally makes the point that medicines have been distributed in France by the clergy since the reign of Louis XIV and concludes his proposal by stating: "This project, if applied to the Greek Orthodox and the Protestant clergy has another great advantage for the clergy themselves, as it would provide careers for their children."

Count de Wargemont's proposals to place the entire medical education and the practice of medicine in Russia into the hands of the Church did not meet with Frank's unqualified approval. In the first place, he did not agree that every student of theology should be obliged to study medicine. This should only apply to prospective rural priests, while the clergy in more populated areas and in towns could devote themselves entirely to their ecclesiastical duties. He was particularly opposed to the idea to "drive medicine back into the monasteries". This, he thought, would in any case be impracticable as in many countries the monasteries were in the process of being dissolved and as in Russia were neither enough monasteries available, nor were the existing ones suitably organized for this purpose.

Count de Wargemont himself was informed of some of the objections to his plan by dignitaries of the Greek Orthodox Church. It was thought that the practice of medicine was not compatible with the dignity of the holy ministry. De Wargemont replied to these objections in a letter addressed to Frank, pointing out that Christ himself did not find it below his dignity to heal people. This letter is reproduced in a footnote. ${ }^{56}$

Frank voices the opinion that it would have been to the greatest advantage for the rural population in Russia if the Greek Orthodox Church would not have refrained from the study and the practice of medicine for many centuries, especially as there were in Russia so many vast areas without any medical service. The population of many provinces would have been doubled or even trebled by reducing the appalling infant mortality and by improving the peasants' health by appropriate care. There seemed to be no other easily applicable method of extending medical care than the creation of priest-doctors. In Russia there was only a small middle class situated between the nobility and the serfs. Therefore the medico-chirurgical academies in

so Ibid., pp. 447-449. 


\section{"Priest-doctors" as a rural health service in the age of Enlightenment}

St. Petersburg and Moscow had to draw chiefly on the sons of priests to obtain a barely sufficient number of students to fill the positions of army surgeons. Education being in the hands of the Church, the holy Synod had to arrange to release a number of students for medical studies, but could in his times never raise more than fifty students per year. The holy Synod was therefore in a quandary, either to send, to her own loss, the best pupils to the academies, or only to release the weakest ones. If, however, the sons of the rural clergymen could remain in the profession of their fathers but serve the people as priests and doctors at the same time, the medical needs of the country population would be met, at least for the time being. The army, on the other hand, would probably not lose any more prospective surgeons than they could expect to raise from the ranks of the middle class and the poorer nobility, provided the pay and status of the army surgeon could be improved.

Some initial action was taken by Tsar Alexander I by issuing an Imperial ukase which Frank reprints as follows: ${ }^{57}$

URASE OF TSAR ALEXANDER I

My intention to remedy the absence of medical provisions in the villages by arranging for the rural population to be assisted also in their bodily illnesses by their own priests will be made clear by the following text of My command to the holy Synod to institute the appropriate instruction in the religious colleges of the Empire.

The executive Senate is ordered to issue the appropriate instruction to the Medical Collegium and in future to support My project in every possible way.

It is general knowledge that our villages are not provided with doctors and that even otherwise trivial accidents and illnesses end fatally owing to ignorance, deeply rooted prejudices and to treatment contrary to simple reason and the nature of the illness.

As it is My wish to afford the rural population simple succour in their illnesses in accordance with their mode of living and it is My opinion that the medical care of patients in rural areas should be entrusted to the rural clergymen, after the latter had been given the opportunity to learn the principles of medicine in addition to their own clerical studies.

To achieve this purpose it is necessary that the holy Synod should make the following provisions, as their own contribution to this humane project.

(1) That to the fifty pupils, which the clerical schools have to send every year to the medical and surgical academies, should be added a certain number of pupils, at the same cost, so that those should be appointed as teachers of the above-mentioned sciences in the seminaries after the completion of their studies and their return to their native parishes.

(2) That during the time these future teachers pursue their studies the Medical Collegium should compile concise and easy-to-follow instructions how to treat the diseases most common in rural areas with medicines which should be easily produced in a village. An appropriate number of copies of these instructions should be made available by the Collegium to the Holy Synod, which, in turn, should distribute these to the clerical colleges and rural parishes in the provinces. (3) That the Medical Collegium should instruct the medical committees appointed by the government in every province, to see that some of their most experienced members or the Official District Officers of the province will lecture on the basic principles of medicine in the clerical colleges until the colleges will have their own teachers. They should also assist in other ways to the best of their ability the furtherance of medical knowledge by the clergy.

(4) In accordance with these principal regulations I have ordered the Executive Senate to issue directives to anyone concerned in this matter and I have entrusted Ambrosius, Metropolit of St. Petersburg and Nowgorod, with the supervision of this project and have ordered him to get in touch without delay with the Governor General of the Medical Collegium, Count Wasilieff.

(5) Regarding the ways to excite the zeal of the clergy to co-operate in this project and regarding the payment of the necessary monies for the teachers' salaries and for necessary implements etc., the Holy Synod will report to me after having ascertained the exact amounts.

There were considerable difficulties, and to illustrate them Frank reproduces the ${ }^{37}$ Ibid., pp. 451-454. 


\title{
Robert Heller
}

text of a letter which he received from Count Potocky the curator of the University of Charkov, asking him to devise a syllabus for a course of studies for students of theology which would give them some limited knowledge of medicine. ${ }^{58}$

\begin{abstract}
POTOCKY'S LETTER
His Majesty the Emperor, desiring to procure the means of relief for the rural population in their illnesses, has decreed by Ukase that the young ecclesiastic students should be instructed in the rudiments of medicine.

This has been carried out accordingly as much as possible in the divers seminaries. However, as these establishments have generally only limited means, His Grace the Archbishop of Charkov has permitted the students of these to attend the course of lectures at the university which are very crowded. There arise the following difficulties: (1) By studying all branches of this science they are necessarily distracted from following the main objective of their studies. (2) If one lets them study only some of the subjects one runs the risk of producing semi-doctors, doing more harm than good. It seems, therefore, to be essential to design a curriculum for the preliminary studies of physics, botany and chemistry as well as for those of medicine in which there should be taught just enough as is necessary and nothing above. Such a course should enable the students to combat the superstitions of the common people and also to provide medicines in simple cases of illness and which above all will show them the limits to which to confine themselves without ever to become dangerous to their patients.

Nobody, dear Sir, could devise this plan of studies better than you, who have won yourself a reputation by your widely known publications and by your extensive medical practice. I hope however that you will pardon my importunity and that you will not refuse to undertake this task, which should be so easy for you and which will be most useful for the country which you are about to adopt as your home. Enclosed I am sending you a translation of the Ukase which will inform in detail of the views of our benevolent Sovereign. I am awaiting with impatience your reply and I am. ...
\end{abstract}

Count Severin Potocky.

There is no evidence that Frank ever drew up the curriculum as requested by Count Potocky. He never referred to it again. There can be little doubt that this scheme had gone the same way as many other bold plans sponsored by Alexander I, which were either impossible to be carried out on account of the country's backwardness or stifled by the resistance of the nobility, the Church or the bureaucracy.

As Greek-Orthodox priests were allowed to marry, there were, Frank thinks, less objections to priest-doctors of this clergy than that of the Roman Catholic faith. A married doctor was preferable to a celibate one. On further reflection, however, Frank finds that many doctors married either late or not at all and still practised medicine as respected members of the community, neither were there any legal restrictions regarding bachelors practising medicine. The celibate Roman Catholic priests came also into close contact with their female parishioners and had to advise and guide them often on the most delicate matters. Therefore there should be no objection to celibate priests practising medicine on this account. The Roman Catholic Church obliges doctors to exhort their seriously ill patients to call the priest to administer the last rites. The priest-doctor could fulfil the dual functions of a healer of the soul and body in these circumstances at the same time, without alarming the sufferer. It seems unlikely to Frank that a Roman Catholic priest might be too busy to practise medicine as well. Many people remarked that the priests had not enough duties to occupy themselves and, anyway, it had been done in the past.

The supervision of the priests' medical activities might present some problems,

s8 Ibid., pp. 454-455. 


\section{"Priest-doctors" as a rural health service in the age of Enlightenment}

especially in Catholic countries, where the Church was completely independent. Frank could, however, see no insuperable difficulty there, as the Church had always been prepared to co-operate with the State when necessary. The objection of subjecting medicine to undue prejudice and superstition by putting it into the hands of the clergy seems no longer valid to Frank, as the diffusion of progressive ideas since the invention of the printing press and the general enlightenment of the clergy would be adequate safeguards against this.

The number of candidates for the priesthood was getting smaller year by year. There was danger that eventually many parishes in the country would have to be served by priests with very limited talents or even be left without any priest at all. The main reason for this was the poor remuneration of the rural clergy, which was made worse by the continually rising cost of living. This problem could be solved by increasing the income of the rural clergy. Frank suggests that rural priests should receive a supplement to their income, which need not be more than half or one-third of a doctor's salary. The condition for receiving this supplement would be that the students of theology would also undergo a course of training in the rudiments of medicine and be duly examined by the authorities on completion of this course. The increased income would enable the rural clergy to live in conditions more suited to their standing. There were of course some priests in Catholic countries who enjoyed excessively rich livings. Frank thinks that Church and State should see to it that these incomes should be more equably distributed.

The priest-doctor would have to possess a good knowledge of the rudiments of surgery. The peasants, engaged almost entirely in manual work, were particularly prone to accidents and a person unable to deal with these would be of little use. Conditions requiring major operations would of course still be the concern of the official district surgeon and so would be medico-legal matters and official reports on the health of the district.

Regarding midwifery, the priest-doctors would have to have some knowledge of this subject, to be able to supervise effectively the village midwife, but especially in Catholic countries it would not be possible for the priest-doctor to engage in midwifery himself. Frank suggests however, that in Greek-Orthodox and Protestant countries the clergymen's wives would be eminently suitable to assume the role of midwives themselves, especially as it was generally difficult to find a woman in country areas who could read or write.

Frank thought that he had proved that there should be no serious objection to priests practising medicine, as they had done so anyway during the first thousand years of Christianity. This practice was discontinued by a decree involving Church discipline. The fact that Jesuits were allowed to practise medicine in their missions proved that there was no religious dogma involved. If his suggestion should nevertheless fail to gain approval of the Church he would submit to the better judgement of her dignitaries, but he would be unable to suggest any other means to help the rural populations. These were at present either completely neglected or, even worse, inexcusably delivered into the murderous hands of quacks.

If, however, his project of the priest-doctors were accepted, at least by the Protestant or Greek-Orthodox Churches, the question of adequate training of the candidates 


\section{Robert Heller}

would arise. A suitable balance between theology and medicine would have to be maintained. Country folk were free from many diseases which affected the town dwellers. In the towns the inhabitants suffer from the effects from being crowded into a confined space, of many injurious trades and occupations, of excessive use of the brain leading also to inactivity of the body. It followed from this that doctors who treated country people would never see the host of diseases which town people were subject to. Therefore country doctors need not necessarily be taught about these diseases. Extensive knowledge of anatomy would be a costly luxury, as long as the country doctor would know just the rudiments of this discipline. An extensive knowledge of physiology, so important for a fully trained doctor, would have little value for a person only concerned with simple treatment of a restricted number of diseases. As long as the prospective country doctors had a sufficient grounding in the basic principles of botany and chemistry, there was little more they would need to know in connexion with pharmacy, materia medica, and practical therapy.

Frank has little doubt that candidates for the rural clergy, who had been selected after having completed their preliminary studies which included philosophy and natural history, could be made into useful country doctors without detriment to their theological studies. The prospective priest-doctors should be taught by one professor only, and not, as in the medical faculty by perhaps eight or ten different lecturers. The time spent on instruction should not exceed two hours daily, the lectures being delivered by one teacher only. There would be no confusing contradictions which students might be hearing at lectures by different professors. The course should take three years.

In the first year the rudiments of anatomy and physiology should be taught, as well as general pathology. The second year should be devoted to the teaching of general therapeutic principles and materia medica, the knowledge of instruments, and bandaging. During this time the student should also spend one hour daily at the bedside with his teacher. The third and last year should be spent studying special therapy and practising at the bedside under the supervision of the teacher. It was most important to teach the students the taking of a correct history, so that they might be able to report it to a fully qualified practitioner in case of difficulties. Methods of resuscitation should also be taught. Forensic medicine, medical police and veterinary medicine need not be included in the curriculum. Matters of forensic medicine would be dealt with by the duly appointed district physicians. Regarding public health, the priest doctors would receive clear instructions from the authorities as the circumstances required.

It would of course be necessary to conduct appropriate examinations and to issue certificates to the successful candidates. They should not, under any circumstances, receive a medical degree unless they had successfully completed the full academic course leading to it.

On the last two pages of the chapter, ${ }^{59}$ almost as an afterthought, there are contained two further suggestions. One says that as assistant to the priest-doctor the village schoolmaster could be employed. He could perform duties which would be below the dignity of priests, like applying of plasters, leeches and clysters, bloodletting,

so Ibid., pp. $477-478$. 


\section{"Priest-doctors" as a rural health service in the age of Enlightenment}

cupping as well as bandaging. Schoolmasters would certainly welcome a supplement to their meagre salary and could easily be trained for these duties while still at their training schools.

The other suggestion would in fact have meant the general employment of lay auxiliaries in under-doctored areas. Frank mentions that he by no means wished to imply that only priests should be eventually employed as country practitioners. Any young man, who would be ready to undergo a similar training could of course be appointed to practise medicine in the country.

It seems quite out of keeping that Frank should dismiss the urgent and important subject of lay auxiliaries in one single sentence, while devoting a chapter of one hundred pages to the priest-doctors. It is difficult to understand why Frank did not consider Johann Christian Reil's plan for training medical auxiliaries which had been published in $1804 .{ }^{\circ 0}$ It seems unlikely that he could have overlooked Reil's book, as Hufeland had commented on it in his journal on two occasions. ${ }^{61,62}$ It had also been reviewed at length in the Allgemeine Literaturzeitung. ${ }^{63}$ One possible explanation of Frank's failure to deal with the subject of lay auxiliaries adequately could be that the manuscript for this part of his book had been completed a considerable time before it was published in 1817. By then Frank was already an old man of indifferent health and might have lost interest in this particular subject. ${ }^{64}$ Frank's lack of interest may also have been the reason that he was content to relegate the description of the Swedish scheme for training of priest-doctors to a footnote, albeit a long one. ${ }^{65}$ Under normal circumstances Frank could have been relied upon to report at some length on this scheme devised by the authorities to create a cadre of priest-doctors, especially as it was the only one of its kind that had at last been got under way by any government, at that time.

In Sweden, Linnaeus's original proposal to involve the priesthood in the medical care of their rural parishioners was never completely forgotten during the six decades it took until the Swedish Diet decided to take action. In 1755 the Swedish Commission for Birth, Death and Marriages (Kommissionen för tabellverket) voiced the opinion that the rural clergy should be urged to make themselves familiar with the simpler remedies. ${ }^{68}$ Dahmen quotes a thesis published about the same time at the University of Lund under the title Dissertatio philosophica de sacerdote medico on the great value

${ }^{\infty}$ Reil, op. cit., note 9 above. See also Robert Heller, 'J. C. Reil's training scheme for medical auxiliaries', Med. Hist., 1975, 19: 321-332.

${ }^{61}$ Christian Wilhelm Hufeland, 'Uber Årzte und Routiniers', J. prakt. Heilkunde, Jena, 1805, 21 : 9-21.

"2 Christian Wilhelm Hufeland, 'Bemerkungen über die Reilsche Schrift: Pepinieren zum Unterricht ärztlicher Routiniers u.s.w. und ihre Recension in der Halleschen A.L.Z.', ibid., Berlin, 1807, 26: 9-57.

as Allgemeine Literaturzeitung, Halle, 1804, nos. 325-326-327.

"4 In the foreword to the first supplement volume of his Medicinische Polizey Frank says that although normally supplements were only published after the complete work had been printed, he had decided to publish the supplement there and then, in case he would die before the publication of the entire work. See J. P. Frank, Supplementbände zur Medicinischen Polizey, vol. 1, Tübingen, Cotta, 1812, pp. i-ii. Volume 5 of the main work followed as late as 1813 and volume 6 in 3 parts from 1817-1819.

${ }^{e s}$ Frank, op. cit., note 26 above, vol. 6, part 2, pp. 417-418.

is Otto E. A. Hjelt, Svenska och Finska Medicinalverket historia, vol. 2, Helsingfors, 1892, pp. 215217. 


\section{Robert Heller}

to individual and state of the clergy undertaking some medical practice. ${ }^{67}$ At the University of $\AA$ bo in $1762^{68}$ Samuel Lithovius published and defended a thesis on the importance of the priest having some medical knowledge. ${ }^{69}$ The author suggested that priests without any medical training were neither in a position to discharge their duties, e.g. make good use of the remedies which the authorities distributed in times of epidemics, nor were they qualified to establish the cause of death for entry in the parish register. The author concludes his thesis, as quoted by Dahmén ${ }^{70}$ with the wish that "Gentlemen at college would, with greater regard and diligence than hitherto, especially those who intend for themselves the important state of priesthood, furnish themselves with the necessary insight into the highly important 'studium medicum'."

In Stockholm in 1786 a Royal Command was issued to the effect that the bishops and chapters should not only encourage the students to acquaint themselves with the "knowledge of the elements of medicine" but that the consistories, where one of the lecturers was a medical man, should set an examination in that subject. There is no evidence, however, that this command had any practical results. ${ }^{71}$

During the following two decades the subject of "priest-doctors" was discussed from time to time in the press. Dahmén quotes an example taken from an article in the Biografisket lexicon, ${ }^{72}$ where the author saw the priest as "superintendent of finance, police administrator chief constable and sheriff, an instrument of the local government, and, if God wills, feldsher and physician".

Eventually on 18 August 1809 a plan was submitted to the Swedish Diet regarding the extension of medical care to the rural population. ${ }^{73}$ This proposal was presented by Dr. Carl von Travenfeldt, titular professor of medicine at Stockholm and member of the Riksdag. He suggested that the rural clergy should study and subsequently practise a limited amount of medicine, with the opportunity to consult the salaried district medical officers in more difficult cases. The district medical officers were, in return for their extra consultative duties, to receive increased salaries and free housing. It was recognized that the district medical officers were badly paid and that the rural population was prejudiced against conventional medicine and preferred traditional remedies. The arguments in favour of the rural clergy practising medicine were stated as follows: (1) the priests had the confidence of their parishioners; (2) the state could not afford to appoint as many salaried doctors as were necessary to maintain an effective service in the country and, on the whole, the priests were the best paid servants of the state in Sweden; (3) the practice of medicine would give great satisfaction to the members of the rural clergy and would greatly increase their standing among parishioners; (4) experience had shown that priests who practised medicine did not neglect their clerical duties. To achieve the aims of this project the following

'7 Gunnar Dahmén, 'Prästmedicinen', Kyrkohistorisk Arsskrift, 1943, 3: 128-156 (see p. 129).

c2 Ábo was at that time still a Swedish university. The town of Abo became the capital of the Russian Grand Duchy of Finland in 1809 and bears today the Finnish name of Turku.

9 Dahmén, op. cit., note 67 above, pp. 130-131.

70 Ibid., see footnote to p. 130.

71 Ibid., pp. 130-131.

72 Ibid., p. 131.

78 See note 48 above. 


\section{"Priest-doctors" as a rural health service in the age of Enlightenment}

measures were suggested: natural history, chemistry, dietetics etc. should be taught more thoroughly in the schools; an increased sum of money to be granted by the Diet to cover grants for theological students to study medicine; the creation of a special medical school; the provision of free medicine, etc. A clergyman who had passed the medical examination was to be granted higher seniority. Von Travenfeldt also proposed the creation of a special training school for feldshers for the army, for priests and for students of theology.

The proposals were generally well received and a commission was set up with a view to implementing the plan. Hufeland's article "Medizinische Praxis der Landgeistlichen"74 was said to have greatly influenced the generally favourable reception of the above proposals. The main resistance to the scheme seems to have come from the clergy themselves. ${ }^{75}$

In $1810^{76,77}$ the Swedish Diet voted a sum of 5000 Thalers to provide fifty students of theology with a grant of 100 Thalers each to encourage them to combine medical and theological studies. Thirty-four grants went to students in Uppsala and sixteen to students in Lund. Professor Engelhart ${ }^{78}$ was full of enthusiasm for this scheme and declared himself willing to give lectures in medicine to theological students. The theological faculty at Lund, however, was somewhat doubtful and voiced its misgivings: if one person could follow two professions at the same time, this would, without doubt, be most useful. It would, however, be very difficult to achieve complete mastery of these two complicated subjects. For this reason, as Professor Engelhart had suggested, a shorter course in popular medicine for theological students might be possible, if it could be held within the space of two to three semesters. On the other hand, the theological faculty would consider themselves at fault if they accepted the opinion that a student, even of exceptionally quick grasp, could accumulate sufficient knowledge within two to three semesters to become a good doctor. The faculty wished to point out the disadvantages of a superficial study of medicine, but this did not apply in this particular case, as Professor Engelhart was such an experienced and successful teacher. The rector of the university, the historian Stoberg, supported the setting up of a medico-theological faculty. Engelhart was to give daily lectures of an hour each to theological students. The medical training was to consist of two courses of two semesters each.79

The definitive decree establishing scholarships for "priest-medicine" was eventually issued in 1813. The progress of the scheme was, however, by no means promising and even Engelhart himself had to admit that it had not been successful. ${ }^{80}$ In 1824 the great sum allocated to the provision of grants for "priest-medicine" was reduced to 2000 Thalers, and fourteen scholarships went to Uppsala and six to Lund. In

"4 Hufeland, op. cit., note 44 above.

75 Dahmén, op. cit., note 67 above, pp. 144-155.

${ }^{76}$ Eli Essen-Möller, Bidrag till Lunds Medicinska Facultets Historia, Lund, Glaerup, 1947, pp. 93-97.

77 Goerke, op. cit., note 30 above, pp. 353-358.

78 Johann Henrik Engelhart (1759-1832), Professor of Medicine at the University of Lund, took Holy Orders at the age of fifty-six and assumed the double role of physician and priest. He thus put the principle of the priest-doctor personally into practice. See Essen-Moller, op. cit., note 76 above, p. 96.

70 Ibid pp. 94-95.

${ }^{80}$ Ibid., p. 95. 


\section{Robert Heller}

1826 the Educational Committee stated that the "medico-theological scholarships, on the evidence of experience, hardly seem to have contributed to the attainment of the purpose assigned to them" and it is suggested to convert them into ordinary theological scholarships. ${ }^{81}$ The scheme was ended by distributing the money available, equally, as scholarships to medical and theological students. The medico-theological faculty was formally dissolved in $1841 .{ }^{82}$

Thus, a century and a half ago, the putting into practice of the idea of priest-doctors for a rural health service in Europe was abandoned. This concept held, and is still holding, many advantages for developing countries in need of rapid relief of deficiencies of health care in their rural areas. It certainly deserved a better success in the Age of Enlightenment, even if only as a temporary measure. With the everincreasing demand for health services in the Third World it is therefore hardly surprising that efforts are now being made to revive it. ${ }^{88,84}$

It will have to be left to tomorrow's observers to record the fate of today's priestdoctor schemes.

\section{SUMMARY}

The need to improve the medical care of the rural population was being increasingly realized in Europe during the eighteenth and the early nineteenth centuries. Landowners and rural priests gave medical help on an individual scale, aided by books on popular medicine. The general involvement of the rural clergy in the medical care of their parishioners was suggested by Linnaeus. The concept of a nation-wide rural health service, created by employing the clergyman in the double role of priest and healer, after giving him a short course of medical instruction, seemed very attractive. The setting up of such a scheme would involve the state in little extra expenditure. Johann Peter Frank in 1803 argued that the Catholic Church, on historical and humanitarian grounds, should have little difficulty in reconsidering her negative attitude to medical practice by ordained priests. In 1817 Frank devoted one hundred pages to the subject of priest-doctors in his monumental work on community health, the Medicinische Polizey. This topic was widely discussed in the literature and Frank

81 Dahmén, op. cit., note 67 above, p. 143.

s2 Ibid., p. 144.

${ }^{83}$ As an example of a modern priest-doctor scheme may serve the one proposed by the Ethiopian Orthodox Church. It was suggested to create a Medical Service Department within the office of the Patriarchate to co-operate with the Ministry of Public health. "Hand-in-hand with the creation of the Department for Medical Service could go a priest-dresser training programme. The curriculum for such a programme was worked out by the Ministry of Health. This is a year-long course and would qualify the select group of clergymen to graduate as dressers. They would then be attached to the larger hospitals at Addis Ababa for some time to gain additional experience. Thereafter they would be sent back to hospitals in the rural areas whence they came, to give medical service-in addition to their religious duties in the provinces where they are needed most." Getaneh Bogale, Director, Ethiopian Orthodox Church, Committee on Inter-Church Aid and Refugee Service, personal communication, Addis Ababa, January, 1974. At the time of writing it was not possible to ascertain whether this scheme had made further progress.

84 As a priest-doctor scheme in a non-Christian country, Professor Backett's suggestion to involve the Buddhist monks in Thailand in the medical care of the rural population merits serious attention. This scheme was suggested by Professor E. M. Backett as a personal idea and has, so far, not been officially implemented. E. Maurice Backett, personal communication. 


\section{"Priest-doctors" as a rural health service in the age of Enlightenment}

quoted a number of different authors in favour of, or against the creation of priestdoctors. He also published a proposal by a French count, an official at the court of St. Petersburg, suggesting that the teaching as well as the practice of medicine in Russia should be made the sole responsibility of the Church. Frank gives his own views on the curriculum for the training of priest-doctors in the same chapter of his book. Despite the interest evoked by these schemes, it was only in Sweden, in the first half of the nineteenth century, that a serious attempt was made by a government to put into practice some kind of training scheme for prospective rural priests. The Swedish Diet voted a sum of money to provide study grants for prospective priestdoctors. Lectures in popular medicine were instituted. The scheme, however, was not successful and was eventually abandoned.

\section{ACKNOWLEDGEMENTS}

Many persons have very kindly helped me with this article. I am particularly grateful to the following: Mr. Felix Bloch, Lausanne; Dr. J. Hakan Halberg, World Council of Churches, Geneva; Dr. D. Johnson, Christian Medical Fellowship, London; Dr. R. Schram, Ross Institute, London School of Hygiene and Tropical Medicine; Prof. Dr. A. Imhof, Free University, Berlin; Doz. Dr. B. Lindskog, University of Lund; and Deputy Librarian Dr. C. O. von Sydow of the University of Uppsala; Dr. Katherine Elliott, Assistant Director, Ciba Foundation, London; and Mr. G. Brideson, Librarian of the Linnean Society, London.

My special thanks are due to Mr. Eric Freeman, Librarian, Wellcome Institute for the History of Medicine, London, for his continuous advice and assistance and also to Mr. H. R. Denham, Chief Cataloguer of the same Institute for providing an invaluable translation from the Swedish. 